\title{
PENGARUH JUMLAH DAN SUDUT PEMASANGAN SUDU TERHADAP DAYA TURBIN ANGIN SAVONIUS
}

\author{
Purwoko $^{1}$, Santoso $^{2}$, Nurchajat ${ }^{3}$ \\ 1,2,3 Teknik Mesin, Politeknik Negeri Malang \\ ${ }^{1}$ purwoko_polmal@yahoo.co.id, ${ }^{2}$ santoso_polinema@yahoo.com, ${ }^{3}$ Nurchajat@polinema.ac.id
}

(Artikel diterima: Februari 2020, direvisi: April 2020, diterima untuk terbit: Juli 2020)

\begin{abstract}
Abstrak - The problem in Energy conservation is finding new opportunities for high-efficiency energy generation including wind power generating machines. This study aims to determine the effect of the number and curv angle of blade mounting on the output power of a Savonius type wind turbine. This low speed wind turbine is intended to get energy at the top of a multi-storey building in an urban area. Tests were carried out on a laboratory scale, using savonius wind turbines with a diameter of $400 \mathrm{~mm}$ and a height of $500 \mathrm{~mm}$. The driving wind speed of the turbine is set between 1.5 to $8.5 \mathrm{~m} / \mathrm{s}$. While the number of blades used is 2 types, namely rotor with three blades and rotor with 4 blades, each of which is tested on 3 different types of curv angle blade. The investigation results are expected to show that the wind tubing from each experiment will give different characteristics. The results showed that there was an increase in efficiency in the savonius turbine with blades. The highest rotation and power occur when the turbine uses 2 blades and -50 curv angle of blade mounting
\end{abstract}

Kata kunci: wind turbine, savonius, blade

\section{Pendahuluan}

Dewasa ini energi angin menjadi sumber energi yang mempunyai pertumbuhan paling pesat di dunia. Selama bertahun-tahun turbin angin, terutama turbin angin dengan sumbu poros horisontal digunakan untuk menghasilkan energi listrik yang ramah lingkungan, yang kemudian disuplai ke perkotaan. Kapasitas energi angin di dunia dari tahun ke tahun selalu meningkat dan di tahun 2010 mencapai 196.630 MW. Sayangnya, di daerah-daerah dengan kecepatan angin yang rendah, turbin angin konvensional tidak cocok untuk dipasang, karena turbin-turbin tersebut dirancang untuk bekerja di wilayah dengan kecepatan angin tinggi. Kondisi kecepatan angin rendah dialami oleh daerah di sekitar garis katulistiwa seperti di Indonesia.

Energi angin merupakan energi terbarukan yang sangat fleksibel dan berkembang saat ini. Karena dapat digunakan untuk berbagai keperluan dan mengurangi ketergantungan terhadap energi fosil yang semakin hari semakin berkurang jumlahnya. Untuk memanfaatkan energi angin sebagai pembangkit Sistem Konversi Energi tenaga Angin dibutuhkan kesesuaian teknologi turbin angin dengan karakteristik angin dimana turbin tersebut digunakan. karena jenis dan konstruksi turbin yang berbeda memiliki karakter yang berbeda pula dalam aplikasinya. Menurut beberapa sumber karakter angin di Indonesia memiliki kecepatan bervariatif, umumnya terkategorikan sebagai angin berkecepatan rendah dengan arah angin yang sering berubah dan sering terjadi turbulensi.

Mengacu karakteristik angin tersebut, turbin angin yang cocok digunakan adalah jenis Savonius type U karena beberapa keuntungan, yaitu : tidak memerlukan orientasi pada arah mata angin (tidak perlu mendeteksi arah angin), otomatis menyala sendiri (self starting) menghasilkan tenaga putaran yang lebih tinggi. Diduga rotor Savonius U dengan jumlah sudu yang berbeda akan menghasilkan putaran dan torsi yang berbeda pula, karena pada kecepatan tinggi koefisien drag rotasi akan menjadi lebih tinggi dan dapat menyebabkan kehilangan banyak energi, sedangkan rotor dengan jumlah sudu lebih banyak memiliki massa dan momen inersia yang lebih besar. Untuk itu perlu dilakukan penelitian untuk mengetahui pengaruh jumlah sudu rotor Savonius type $U$ terhadap putaran dan torsi, agar potensi energi angin dapat dimanfaatkan secara maksimal, sesuai kebutuhan pokok paling sedikit untuk suatu pembangkit energi angin, yaitu putaran dan torsi yang besar.

\section{A. Rumusan Masalah}

Beradasarkan uraian permasalahan yang ada dapat dirumuskan beberapa permasalahan sebagai berikut :

- Bagaimana pengaruh jumlah sudu terhadap daya yang dihasilkan oleh turbin.

- Bagaimana pengaruh sudut pemasangan sudu terhadap daya yang dihasilkan oleh turbin.

\section{B. Batasan Masalah}

Mengingat adanya keterbatasan waktu, tenaga, konstruksi dan kompleknya permasalahan dalam penelitian ini, maka penelitian dibatasi sebagai berikut :

- Hanya meneliti jumlah dua dan tiga buah sudu.

- Sudut pemasangan sudu hanya dipersiapkan untuk diatur pada jarak $-5^{0}, 0^{0}$ dan $5^{0}$.

\section{Tujuan Penelitian.}

Tujuan yang ingin dicapai dalam penelitian ini:

- Mengetahui perubahan daya pada variasi jumlah sudu

- Mengetahui perubahan daya pada variasi sudut sudu

\section{Manfaat Penelitian}

Manfaat dari penelitian ini adalah untuk memahami pengaruh jumlah sudu (dua sudu dan tiga sudu) rotor Savonius type $\mathrm{U}$ terhadap daya yang dapat dibangkitkan, serta untuk mengetahui sudut pemasangan sudu efektif yang menghasilkan putaran dan torsi optimal.

\section{Tinjauan Pustaka}

Angin adalah udara yang bergerak yang diakibatkan 
oleh rotasi bumi dan juga karena adanya perbedaan tekanan udara disekitarnya. Angin bergerak dari tempat bertekanan udara tinggi ke bertekanan udara rendah. Pemanasan oleh matahari, maka udara memuai. Tekanan udara yang telah memuai massa jenisnya menjadi lebih ringan sehingga naik. Apabila hal ini terjadi, tekanan udara turun. Udara disekitarnya mengalir ke tempat yang bertekanan rendah. Udara menyusut menjadi lebih berat dan turun ke tanah. Diatas tanah udara menjadi panas lagi dan naik kembali. Aliran naiknya udara panas dan turunnya udara dingin ini dikarenakan konveksi.

B. Altan and M. Atilgan, A Study on Increasing The Performance of Savonius Wind Rotor. Journal of Mechanical Science and Technology 26 (5) (2012) 1493-1499, menyebutkan bahwa panjang dan sudut sudu pengarah pada turbin savonius menunjukan adanya peningkatan daya turbin sampai dengan $75 \%$ dengan penambahan sudu pengarah pada panjang dan arah tertentu. Banyak faktor dari sudu pengarah yang berpengaruh terhadap peningkatan daya turbin, diantaranya panjang sudu pengarah, bentuk, jumlah dan sudut kemiringan dari sudu pengarah. Untuk menghasilkan daya yang optimal bentuk dari turbin savonius juga harus diperhatikan.

N. H. Mahmoud, A. A. El-Haraoun, E. Wahba, M.H. Nasef, An experimental study on improvement of Savonius rotor performance, Alexandria Engineering Journal (2012) 51, 19-25. menyebutkan bahwa Turbin savonius mampu menghasilkan daya yang baik pada kecepatan rendah adalah turbin yang memiliki 2 buah sudu dan memiliki end plate atau penutup pada bagian atas dan bagian bawah turbin.

Y. X. Yao, Z. P. Tang, X. W. Wang, Design based on a parametric analysis of a drag driven VAWT with a tower cowling, Journal of Wind Engineering and Industrial Aerodynamics, 116 (2013) 3239. menyatakan bahwa Sudu pengarah mampu meningkatkan unjuk kerja aerodinamika turbin angin. Semakin bertambahnya sudut kemiringan sudu pengarah, akan semakin meningkatkan kecepatan angin yang sampai ke rotor, sehingga daya yang dihasilkan akan semakin meningkat.

\section{Metode Penelitian}

\section{A. Peralatan dan Instrumen}

Dalam penelitian ini menggunakan turbin Savonius dengan 2 dan 3 sudu rotor, seperti yang ditampilkan pada Gambar 4.1, dengan diameter $180 \mathrm{~mm}$ dan tinggi $180 \mathrm{~mm}$.

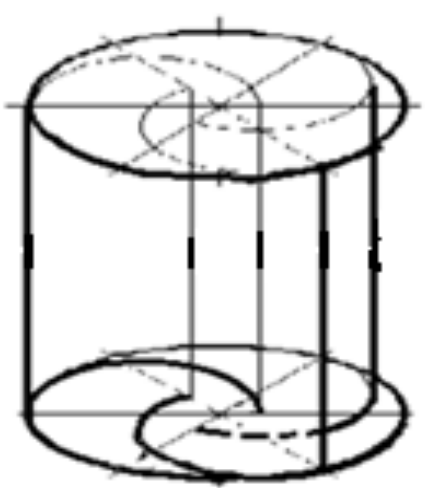

Gambar 4.1. Rancangan Konstruksi Rotor 3 sudu
Dimensi utama rotor adalah :

Masing-masing Jumlah sudu : 2

Diameter rotor $180 \mathrm{~mm}$

Tinggi rotor $180 \mathrm{~mm}$.

Sudut pemasangan sudu s $1=-5^{0}$

Sudut pemasangan sudu s $2=0^{0}$

Sudut pemasangan sudu s $3=5^{0}$

\section{B. Material pembuatan Rotor}

Rotor dibuat dengan plat aluminium 1,0 mm untuk sudu dan $1,8 \mathrm{~mm}$ untuk plat.

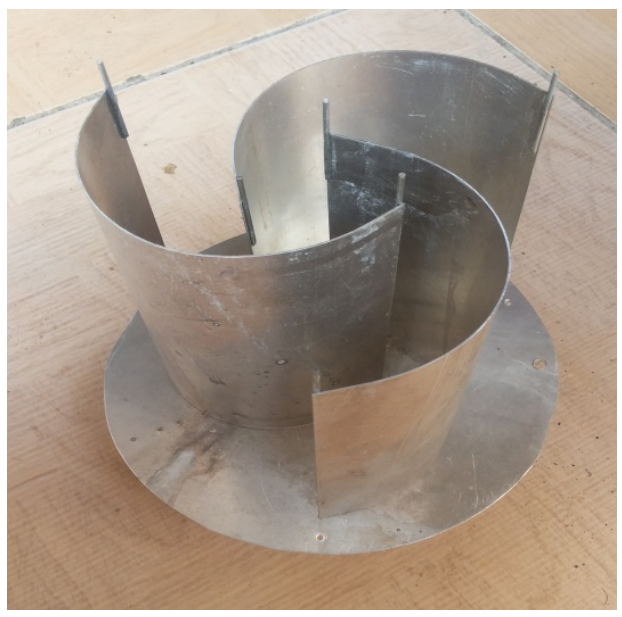

Gambar 4.2. Spesimen Rotor Terpasang 3 sudu
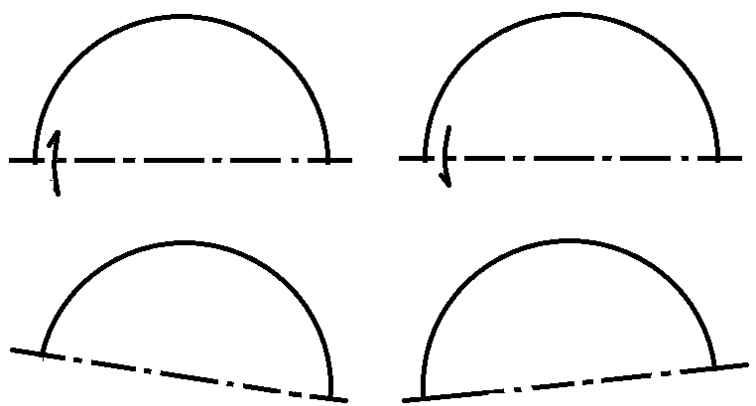

Gambar 4.3. Layout pergeseran sudut sudu

\section{Rancangan Instalasi percobaan}

Rancangan Instalasi percobaan seperti yang ditunjukkan pada gambar. Alat ini berguna untuk mendapatkan data percobaan yang terdiri dari mengontrol/mengukur kecepatan angin dengan merubah putaran fan, mengukur putaran turbin dan mengukur torsi putaran turbin. Peralatan ini terdiri dari beberapa komponen seperti berikut:

- Fan speed controller berguna untuk mengatur putaran fan sehingga diperoleh kecepatan angin antara $1.5-8,5$ $\mathrm{m} / \mathrm{s}$.

- Fan berfungsi untuk mengalirkan angin dalam tunnel

- Tunnel berguna untuk mengarahkan aliran angin ke turbin.

- Anemometer utuk mengukur laju aliran udara dalam tunnel

- Dinamometer untuk mengukur besarnya torsi putaran turbin 
- Odometer berguna untuk mengukur putaran turbin

- Komputer untuk menyimpan dan mengolah data tersebut diatas.

\section{Rancangan dan Teknik Pengumpulan Data}

Penelitian ini adalah untuk memperoleh data-data putaran pada turbin dan torsi. Sedangkan variabel bebasnya adalah kecepatan angin, jumlah dan sudut sudu.

Pengambilan data dimulai dengan mempersiapkan materi penelitian. Seperangkat pengukur dan pengaturan jumlah dan sudut sudu. Penelitian ini dilakukan secara eksperimen di Laboratorium Teknik Mesin, Polinema. Spesimen pengujian dan detail rancangan penelitian ini dapat dilihat pada gambar 4.4.

Penelitian ini mempunyai dua variabel yaitu variabel bebas dan variabel terikat kedua variabel tersebut adalah:

- Variabel bebas : kecepatan angin, jumlah sudu dan sudut sudu

- Variabel terikat : kecepatan putar turbin, torsi

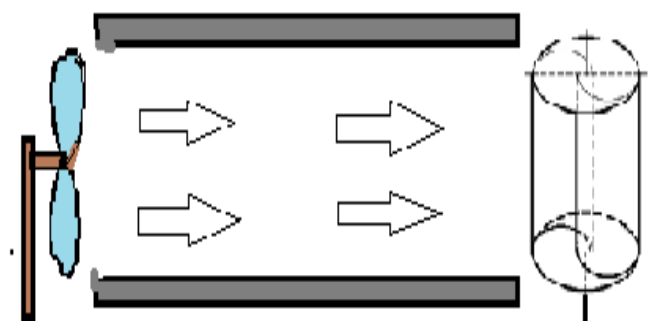

Gambar 4.4. Rancangan Instalasi percobaan

\section{E. Variabel-variabel yang akan diteliti}

\section{Pengukuran kecepatan angin}

Kecepatan angin diperoleh dengan data dengan menempatkan anemometer pada daerah aliran angin. Sedangkan kecepatan angin diatur dengan speed controller yaitu dengan switch yang dipasang untuk merubah arus sehingga putaran fan berkurang atau bertambah.

\section{Pengukuran Torsi}

Untuk mengukur torsi dilakukan dengan cara mekanis sederhana dengan memasang bandul yang mempunyai masa tertentu, yang bergesek pada drum turbin. Sehingga besarnya torsi dihitung dari sudut yang dibentuk oleh bandul.

\section{Hasil Penelitian Dan Pembahasan}

\section{A. A Data Hasil Penelitian}

Tabel 5.1. Data kecepatan angin, putaran turbin, dan sudut bandul

\begin{tabular}{|c|c|c|c|c|c|}
\hline No & $\begin{array}{l}\text { Jenis Turbin } \\
\text { Savonius }\end{array}$ & $\begin{array}{l}\text { Sudut kurva } \\
\text { sudu }(\%)\end{array}$ & $\begin{array}{l}\text { kecepatan angin } \\
(\mathrm{m} / \mathrm{s})\end{array}$ & $\begin{array}{l}\text { Putaran turbin } \\
\text { (rpm) }\end{array}$ & $\begin{array}{l}\text { Sudut } \\
\left({ }^{\circ}\right)\end{array}$ \\
\hline 1 & \multirow{5}{*}{ dua sudu } & \multirow{5}{*}{-5} & 3,2 & 126 & 10 \\
\hline 2 & & & 4 & 132 & 12 \\
\hline 3 & & & 4,3 & 152 & 14 \\
\hline 4 & & & 4,7 & 172 & 15 \\
\hline 5 & & & 4,8 & 186 & 17 \\
\hline 6 & \multirow{5}{*}{ dua sudu } & \multirow{5}{*}{0} & 3,1 & 110 & 13 \\
\hline 7 & & & 3,2 & 120 & 14 \\
\hline 8 & & & 4,5 & 124 & 16 \\
\hline 9 & & & 4,6 & 140 & 18 \\
\hline 10 & & & 4,7 & 149 & 20 \\
\hline 11 & \multirow{5}{*}{ dua sudu } & \multirow{5}{*}{5} & 3,4 & 104 & 9 \\
\hline 12 & & & 3,7 & 108 & 10 \\
\hline 13 & & & 4,2 & 114 & 11 \\
\hline 14 & & & 4,6 & 122 & 13 \\
\hline 15 & & & 4,8 & 144 & 15 \\
\hline
\end{tabular}

Tabel 5.2. Data kecepatan angin, putaran turbin,dan sudut bandul

\begin{tabular}{|c|c|c|c|c|c|}
\hline No & $\begin{array}{l}\text { Jenis Turbin } \\
\text { Savonius }\end{array}$ & $\begin{array}{l}\text { Sudut kurva } \\
\text { sudu (") }\end{array}$ & $\begin{array}{l}\text { kecepatan angin } \\
(\mathrm{m} / \mathrm{s})\end{array}$ & $\begin{array}{l}\text { Putaran turbin } \\
\text { (rpm) }\end{array}$ & $\begin{array}{l}\text { Sudut } \\
\left({ }^{\circ}\right)\end{array}$ \\
\hline 1 & \multirow{5}{*}{ tiga sudu } & \multirow{5}{*}{-5} & 3,1 & 85 & 7 \\
\hline 2 & & & 4,2 & 110 & 9 \\
\hline 3 & & & 4,5 & 115 & 10 \\
\hline 4 & & & 4,6 & 118 & 11 \\
\hline 5 & & & 4,7 & 122 & 12 \\
\hline 6 & \multirow{5}{*}{ tiga sudu } & \multirow{5}{*}{0} & 3,1 & 79 & 5 \\
\hline 7 & & & 4,1 & 100 & 5 \\
\hline 8 & & & 4,6 & 110 & 6 \\
\hline 9 & & & 4,7 & 116 & 7 \\
\hline 10 & & & 4,8 & 120 & 8 \\
\hline 11 & \multirow{5}{*}{ tiga sudu } & \multirow{5}{*}{5} & 3 & 71 & 6 \\
\hline 12 & & & 4,1 & 84 & 7 \\
\hline 13 & & & 4,6 & 92 & 8 \\
\hline 14 & & & 4,7 & 104 & 9 \\
\hline 15 & & & 4,8 & 110 & 10 \\
\hline
\end{tabular}

\section{B. Pembahasan}

Data dari hasil percobaan dapat ditampilkan dalam grafik kecepatan angin terhadap besarnya putaran turbin seperti gambar 5.1. 


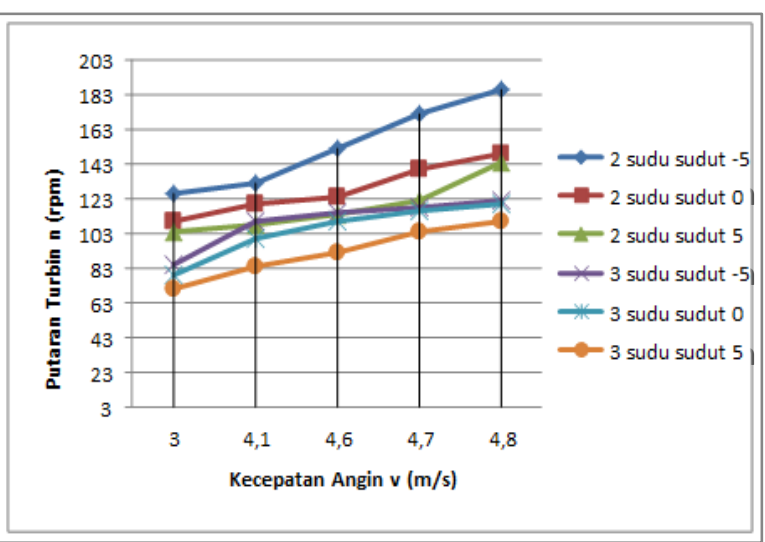

Gambar 5.1 Kinerja Turbin ditunjukkan oleh grafik kecepatan angin \& Rpm

Pada seluruh kondisi kecepatan angin yang bervariasi instalasi turbin dengan dua sudu dan dan sudut sudu $-5^{0}$ mempunyai hasil putaran yang paling tinggi. Hal ini dapat dijelaskan bahwa pada kecepatan angin yang tinggi putaran turbin akan tinggi juga. Kondisi ideal dorongan angin akan sedikit lebih lambat sehingga sisi sudu yang sudutnya digeser untuk mendahului arah putaran kecepatan tinggi akan diperoleh ketepatan waktu antara dorongan angin dan saat sisi sudu tepet nol derajat. Jika demikian aliran akan mengalami ketepatan arah dan kecepatan angin dengan putaran turbin.

Penjelasan ini akan sebaliknya jika diterapkan pada sudut sudu yang tepat nol derajat. Jika kondisi turbin dengan kecepatan tinggi maka arah dan dorongan angin akan cenderung terlambat. Saat tepat sisi sudu lurus dengan arah dan kecepatan angin luas penampang belum terlalu besar dan berakibat tidak menimbulkan energi yang cukup besar. Namun jika kecepatan angin tidak terlalu besar dan putaran tidak terlalu tinggi kondisi ini sangat menguntungkan karena efisiensinya masin cukup tinggi.

Dalam hal penempatan sudu yang kurang tepat juga akan menimbulkan koefisien discharge yang besar dan effisiensi jadi makin kecil. Jika dilihat dari penampang susunan sudu akan lebih jelas seperti terlihat dalam gambar 5.2

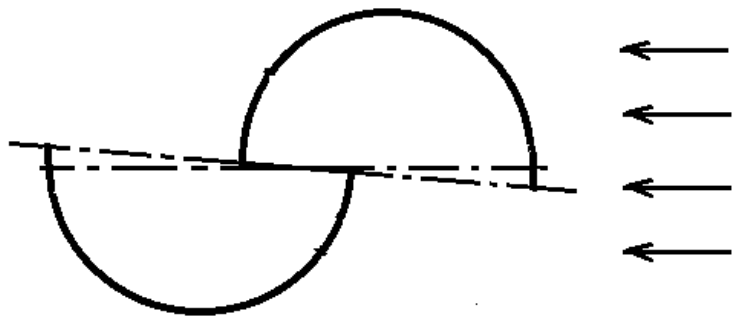

Gambar 5.2 Turbin Savonius Dua sudu sudut sudu $-5^{0}$

Tidak demikian jika aliran tidak melewati perubahan penampang yang signifikan perubahan streamline akan dapat dihindari. Energi angin akan semakin banyak terserap ke sistem turbin hingga putaran dan dayanya menjadi lebih besar.

Pada konstruksi ini yaitu dengan 2 sudu dan sudut sudu lebih maju maka perubahan penampang itu terjadi tidak begitu signifikan sehingga tidak menimbulkan schock dan tidak banyak kehilangan energi. Angin mengalir akan membentuk streamline yang merata terlebih jika kondisi kecepatan angin sedang sampai cukup tinggi. Pada kondisis ini menimbulkan koefisien discharge yang tidak berarti dan effisiensi yang dicapai menjadi semakin besar.

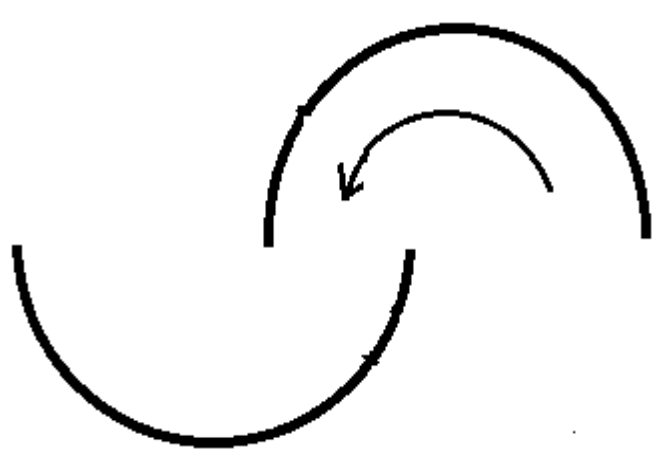

Gambar 5.3 Turbin Savonius Dua sudu sudut sudu $0^{0}$.

Sedangkan pada instalasi turbin dua sudu, dengan sudut sudu 00 torsi akan terjadi pada setiap tepat bersudut 180 derajat, sehingga keadaan ini akan menimbulkan kehilangan start saat letak sudu lurus dengan arah angin, atau gaya torsi belum muncul sampai melewati sudut lurusnya. Pada posisi ini tidak ada sudu yang sesuai posisinya dapat menyerap energi angin yang mengalir. Sehingga jika menghendaki tetap menggunakan dua sudu dan bersudut nol derajat maka konstruksinya harus dibuat berbeda misalnya dibuat sudu miring atau bisa dengan konstruksi bertingkat.

Posisi dua sudu dengan sudut nol derajat yang berposisi sejajar dengan arah angin dapat dilihat pada gambar penampang gambar 5.4

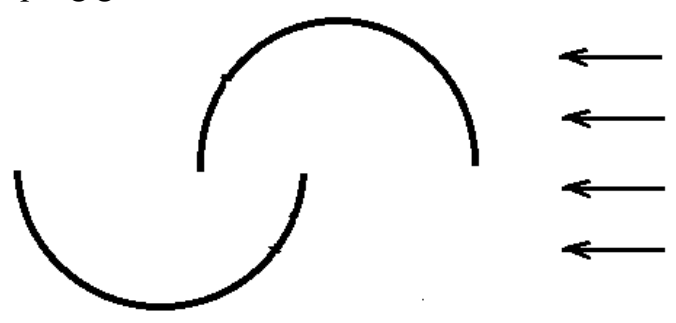

Gambar 5.4 Arah Angin sejajar dengan sudut sudu $0^{0}$.

Pada instalasi dua sudu bersudut nol derajat dapat dijelaskan secara umum bahwa konstruksi ini akan terjadi pengisian yang terlambat aliran angin terlihat penampang instalasi dengan dua sudu pada gambar. Sudut sudu dengan membuka awal jika kecepatan turbin tinggi angin seolah akan terlambat mengalir pada celah awal.

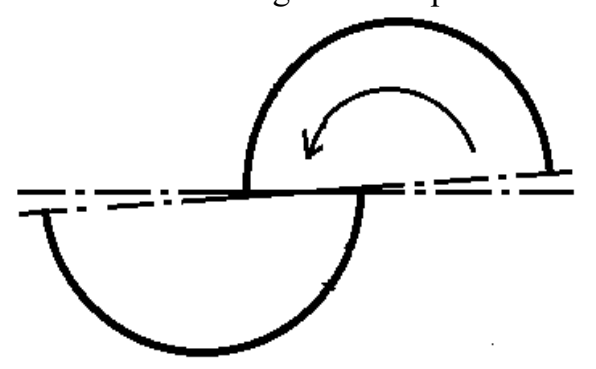

Gambar 5.5 Arah angin dan celah awal pada pemasangan +50

\section{Pembahasan Daya Turbin}

Seperti halnya pada putaran turbin, daya turbin dari hasil 
eksperimen pada seluruh kondisi spesimen baik yang instalasi dua sudu yang bersudut masing-masing -5, 0 maupun yang +5 derajat menunjukkan bahwa semakin besarnya kecepatan angin akan diikuti besarnya daya yang cenderung naik. Disamping itu konstanta kemiringan peningkatannya juga hampir sejajar. Seperti pada hubungan kecepatan angin dan putaran turbin, bahwa ada hubungan linear antara besarnya kecepatan angin dan daya yang terjadi. Dalam kondisi kecepatan angin yang masih rendah yang berarti masih dalam bilangan yang dibawah angka Reynold 3000, sehingga aliran masih dalam kondisi laminer.

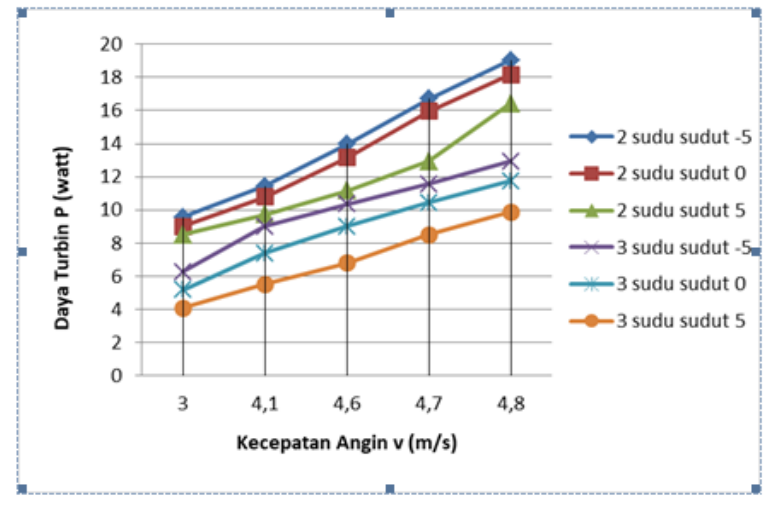

Gambar 5.6. Kinerja Turbin ditunjukkan oleh hubungan kecepatan angin \& Daya

\section{Simpulan Dan SARAN}

\section{A. Simpulan}

Dari hasil penelitian analisa Pengaruh Jumlah dan overlap sudu Terhadap daya turbin Savonius dapat diberikan beberapa kesimpulan antara lain :

- Terdapat perbedaan perbedaan putaran, daya dan penyerapan energi angin pada turbin Savonius dengan variasi jumlah dan sudut sudu.

- Penyerapan energi terbesar yang berarti terjadi putaran dan daya turbin yang terbesar yaitu pada konstruksi menggunakan dua susu dan dengan sudut $-5^{0}$. Pada kondisi ini terjadi pada kecepatan angin adalah 4,8 meter/detik, putaran yang terjadi $120 \mathrm{rpm}$ dan daya turbin sebesar 12,93 watt.

\section{B. Saran}

Dari hasil penelitian ini peneliti memberikan saran antara lain adalah penelitian selanjutnya dapat dilakukan dengan memfokuskan pada turbin Savonius dua sudu dengan memvariabelkan besarnya radius sudu dengan panjang kurva yang sama, dengan tetap membuat sudut sudu miring atau membuat sudu helik, untuk memperoleh penyerapan daya yang optimal. Karena diharapkan dengan dimensi sudut sudu dan garis singgung kurva yang berbeda akan diperoleh efisiensi yang semakin besar, dengan tetap memperhatikan kerugian akibat konstruksinya.

\section{Daftar Pustaka}

[1] W. T. Chong, A. Fazlizan, S. C. Poh, K. C. Pan, H. W. Ping, Early development of an innovative building integrated wind, solar and rain water harvester for urban high rise application, Energy and Buildings 47, 2012, 201-207.
[2] S. Martens, Wind energy in urban areas.Refocus March/April 2002:22-4 